\title{
A new methodology for polyvalent intravenous immunoglobulin solution production with a two-stage process of viral inactivation
}

\author{
Antônio Edson de Souza Lucena ${ }^{1,2 *}$, Divaldo de Almeida Sampaio ${ }^{3,4}$, Ednaldo Rosas da Silva ${ }^{3}$, \\ Virgínia Florêncio de Paiva ${ }^{3}$, Ana Cláudia Santiago ${ }^{3}$, Ana Cristina Lima Leite ${ }^{2,3}$
}

\begin{abstract}
${ }^{1}$ Brazilian Blood Derivatives and Biotechnology Company (HEMOBRÁS), ${ }^{2}$ Department of Pharmaceutical Sciences Federal University of Pernambuco -UFPE, ${ }^{3}$ Hematology and Hemotherapy Foundation of Pernambuco, HEMOPE, Healt Bureau of Pernambuco State Government, ${ }^{4}$ Department of Clinical Medicine, Federal University of Pernambuco
\end{abstract}

\begin{abstract}
Highly purified intravenous immunoglobulin G concentrate (IV IgG) was produced with the use of polyethylene glycol associated to a single-stage precipitation by ethanol, instead of the classic CohnOncley process, which employs cold alcohol as the precipitating agent, in a three-stage process. Precipitation of crude fraction containing more than $95 \%$ of immunoglobulin $\mathrm{G}$ was performed by liquid chromatography with a cation exchanger, CM-Sepharose, as a stationary phase. During the process, the product was subjected to two-stage viral inactivation. The first stage was performed by the action of sodium caprylate, $30 \mathrm{mM}$ at $\mathrm{pH} 5.1+/-0.1$, and the second stage was performed by the action of a solvent-detergent mixture. The finished product was formulated at $5 \%$ with $10 \%$ sucralose as the stabilizing agent. The process yields $3.3 \mathrm{~g}$ of $\mathrm{IgG} /$ liter of plasma. The finished product analysis showed an anti-complementary activity lower than $1 \mathrm{CH}_{50}$. Polymer and aggregate percent levels were lower than $3 \%$ in the five batches studied. The analysis of neutralizing capacity showed the presence of antibacterial and antiviral antibodies in at least three times higher concentrations than the levels found in source plasma. The finished product fulfilled all purity requirements stated in the 4th edition of the European pharmacopeia.
\end{abstract}

Uniterms: Blood derivatives. Immunoglobulins. Polyethylene glycol. Ultrafiltration. Ion exchange chromatography.

Obteve-se concentrado de imunoglobulina G intravenosa IgGIV, altamente purificado, utilizando-se polietilenoglicol associado a uma única etapa de precipitação por etanol, em substituição ao tradicional método descrito por Cohn-Oncley, que emprega, em três etapas, o mesmo álcool resfriado, como agente precipitante. A purificação da fração bruta contendo mais de $95 \%$ de imunoglobulina $G$ foi realizada utilizando-se cromatografia líquida com um trocador de cátion, a CM-Sepharose, como fase estacionária. Durante o processamento o produto foi submetido a dupla inativação viral sendo a primeira pela ação do caprilato de sódio, $30 \mathrm{mM}$ a pH 5,1+/- 0,1 e a segunda por ação de mistura de solvente/ detergente. O produto acabado foi formulado a $5 \%$ utilizando-se sucralose $10 \%$ como estabilizante. $\mathrm{O}$ rendimento da metodologia foi de $3,3 \mathrm{~g}$ de $\mathrm{IgG} /$ litro de plasma. A análise do produto acabado demonstrou atividade anti-complementar inferior a $1 \mathrm{CH}_{50}$. $\mathrm{O}$ valor percentual de polímeros e agregados em cinco lotes realizados foi inferior a 3\%. O estudo da capacidade de neutralização demonstrou a presença de anticorpos anti-bacterianos e anti-virais em concentração pelo menos três vezes maior que o plasma de origem. O produto acabado apresentou conformidade com todos os requisitos de pureza dispostos na farmacopéia européia IV edição.

Unitermos: Hemoderivados. Imunoglobulinas. Polietilenoglicol. Ultrafiltração. Cromatografia de troca iônica.

\footnotetext{
*Correspondence: A. E. S. Lucena. Empresa Brasileira de Hemoderivados e Biotecnologia - HEMOBRÁS, SCN Quadra 01 - Projeção "E" - Central Park $15^{\circ}$ Andar - 70711-903 - Brasília - DF, Brasil. E-mail: antonio.edson.lucena@hotmail.com
} 


\section{INTRODUCTION}

Blood derivatives are biologic medicines produced from industrial fractionation of human plasma, and subjected to industrialization and normatization processes that confer quality, stability, activity, and specificity (RDC 46, 2003). Among these products, intravenous immunoglobulin $\mathrm{G}$ concentrates, IV IgG, play a prominent role, with a growing world demand in the last decade due to their new therapeutic applications (Lloret, 2008). This demand is expected to reach 100 tons by 2012 (Robert, 2006).

Martha (2004) carried out a literature review of the history of immunoglobulin replacement therapy since the discovery of antibody capacity to neutralize antigens, described by Kitasato in 1890 , up to the present day. The therapeutic advantage of intact molecules from IV IgG concentrates has also been reported in comparison to enzymatically modified products (Berger, 2008).

The first papers reporting the production of concentrates containing intact molecules were published in the 1990s. A methodology of IV IgG production, fully developed by liquid chromatography, has also been described (Tanaka, 1998). Although liquid chromatography processes have an established role in the protein purification industry, precipitation techniques for primary isolation of biological material continue to attract the interest of researchers, mainly because of their low cost (Chang, 2000; Buchacher, 2006).

Indeed, chemical agents capable of altering plasma protein solubility, without causing their denaturation, have been frequently used in research laboratories for the purification of small quantities of proteins. (Lebing, 2003). Polyols, particularly polyethylene glycol (PEG), have for many years attracted the interest of the blood derivative industry. Curling (1980) presented a plasma fractionation method using polyethylene glycol as a precipitating agent. Curling concluded that PEG presented considerable advantages of use compared to ethanol, and may shortly be widely used in the production of blood derivatives. Polyethylene glycol has recently been employed in human plasma fractionation for the production of a crude fraction of immunoglobulin which was kept in a solution, and then treated with two-stage ion exchange chromatography (Teschner, 2007).

Octanoic acid is another precipitating agent frequently used in the purification of biological products. Chanutin and Curnish (1960) assessed the inherent characteristics of short-chain fatty acids $\left(\mathrm{C}_{6}-\mathrm{C}_{12}\right)$ for plasma protein precipitation in an acid medium. The authors concluded that, among the compounds tested, caprylic acid $\left(\mathrm{C}_{8}\right)$ presented higher precipitation efficiency. They also concluded that gamma globulins induced less precipitation than alpha- globulins and beta-globulins. This paper was a starting point for the development of several other IgG purification methods, using caprylic acid as a primary stage in the production of immunoglobulins $\mathrm{G}$.

Lebing and cols. (2003) reported the production of a highly purified concentrate, associating precipitation by caprylic acid with other purification processes. Contaminant proteins were extracted with caprylic acid 20 $\mathrm{mM}$ in acid $\mathrm{pH}$, placing the IgGs in solution, which were then subjected to double ion exchange chromatography after clarification, the first with a cation exchanger, and the second with an anion exchanger (Lebing et al., 2003).

In view of the evidence found in the literature and the need to establish new technologies for the production of blood derivatives in Brazil, the aim of the present paper was to develop an alternative methodology to the classic method of cold ethanol, for the production of a solution containing immunoglobulin $\mathrm{G}$ concentrate. In order to achieve this goal, a combination of two non-denaturing chemical agents (caprylic acid and polyethylene glycol) was tested in the precipitation of protein fractions. Detergent action of caprylic acid, described by Lundblad, (1991) was also assessed in the inactivation of enveloped viruses.

\section{MATERIALS AND METHODS}

Arithmetic mean values from results of the analysis of the quality parameters within three experimental batches were computed. All techniques employed during purity assays for the product in process and for the finished product are according to the Pharmacopeia. The Biuret method was used in protein content determination during process control, while the Kjeldahl method was employed for the finished product. Purity of the concentrates obtained was assessed by agarose gel electrophoresis according to the guidelines of the European Pharmacopeia (EP). Molecular integrity was assessed by HPLC with $600 \mathrm{x}$ $75 \mathrm{~mm}$ columns, according to EP monograph (2.2.29 EP monograph, 5th edition). IgA and IgM quantification was performed by ELISA (enzyme-linked immunosorbent assay). Anti-complementary activity was determined according to its specific monograph (2.6.17 EP monograph, 5 th edition). The ELISA test for the finished product was non-reactive during the study of antibodies screened for blood donation, such as anti-HIV ${ }_{1}$ and anti-HIV $\mathrm{H}_{2}$ and also antibodies against hepatitis B surface antigens. The presence of antibacterial antibodies was detected by hemagglutination. The presence of antiviral antibodies not screened in the blood center was also detected by ELISA test. Figure 1 shows all steps for purification and preparation of immunoglobulin concentrates. 

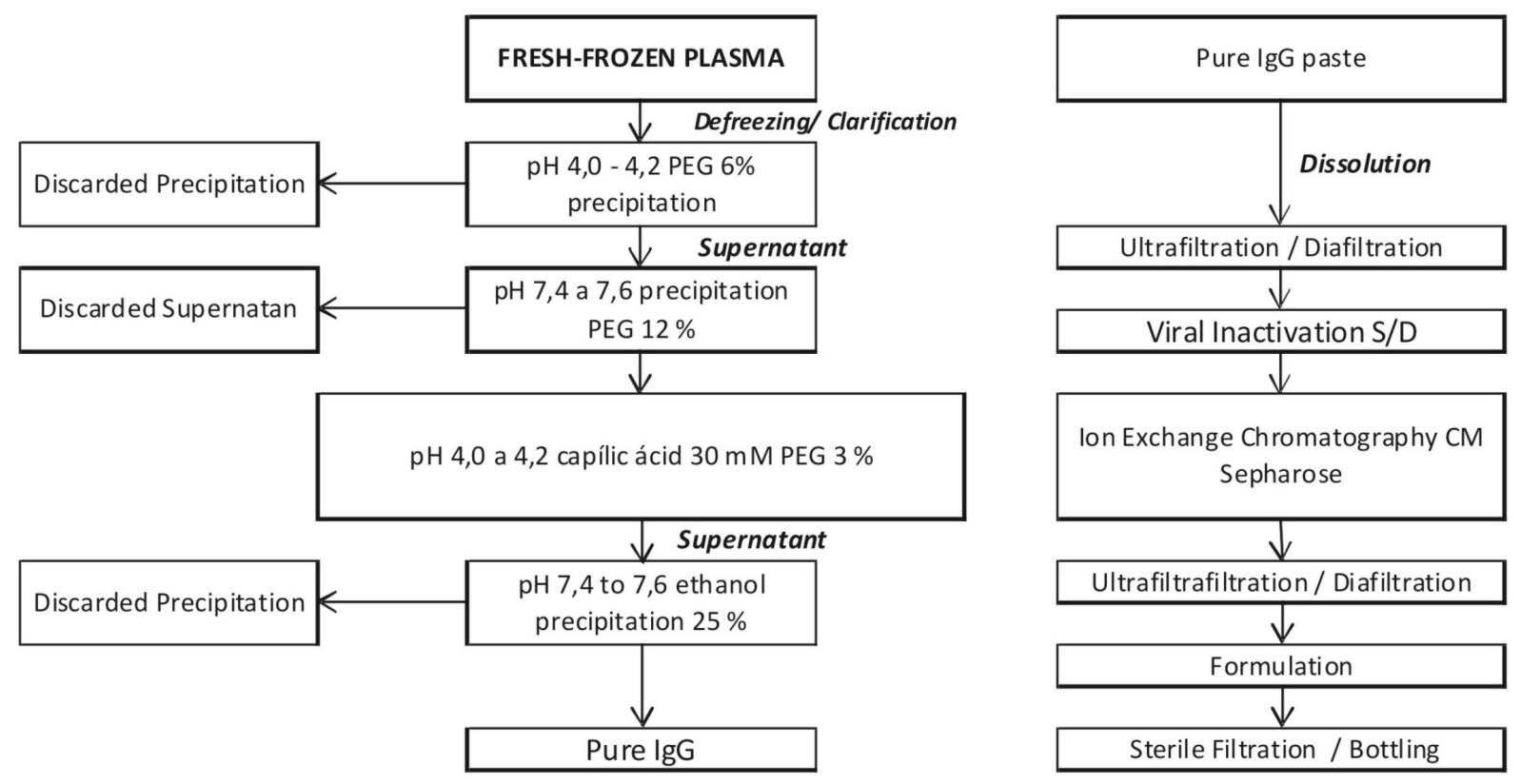

FIGURE 1 - Flow chart showing purification and production of IV IgG 5\% used in the present study.

\section{Production of immunoglobulin G (IgG) crude paste}

The starting material was fresh frozen plasma (FFP), which was thawed at $+4{ }^{\circ} \mathrm{C}$ and then clarified by centrifugation at $12,000 \mathrm{rpm}$. The cryoprecipitate paste recovered was discarded, and supernatant was treated. The first precipitation was obtained by $\mathrm{pH}$ adjustment to $4.1 \pm 0.1$, with acetic acid $0.5 \mathrm{M}$ and the addition of polyethylene glycol q.s.p $6 \% \mathrm{~m} / \mathrm{v}$. After 6 hours under slow homogenization, the precipitate was separated by centrifugation. Supernatant $\mathrm{pH}$ was adjusted to $7.5 \pm 0.1$, and polyethylene glycol q.s.p. $12 \% \mathrm{~m} / \mathrm{v}$ was added. Some immunoglobulin G-rich crude paste was obtained and separated by centrifugation.

\section{$1^{\text {st }}$ Viral inactivation and production of $\lg G$ pure paste}

IgG crude paste was dissolved in water for injection into a quantity equivalent to six times its weight $(\mathrm{kg} / \mathrm{L})$, and its $\mathrm{pH}$ was adjusted to $5.1 \pm 0.1$. Caprylic acid q.s.p. $30 \mathrm{mM}$ was then added. The suspension was kept under constant agitation at $25^{\circ} \mathrm{C} \pm 1{ }^{\circ} \mathrm{C}$ for 1 hour, as the first viral inactivation step (Lundblad, 1991). Polyethylene glycol q.s.p. $3 \% \mathrm{~m} / \mathrm{v}$ was added, with the formation of a precipitate, which was discarded by centrifugation. Supernatant was filtered, and a hyaline solution was obtained. Its $\mathrm{pH}$ was adjusted to $7.3 \pm 0.1$, and then temperature was lowered to close to $0{ }^{\circ} \mathrm{C}$, and the addition of ethanol q.s.p. $25 \%$ was begun. The increase in alcohol concentration took place concomitantly with suspension cooling, such that the product in process temperature was close to $-5^{\circ} \mathrm{C}$ at the end of ethanol addition. After reaching optimum cold temperature, between $-5^{\circ} \mathrm{C}$ and $-7^{\circ} \mathrm{C}$, immunoglobulin precipitation started, and took 8 hours. The precipitate formed, made up of pure $\mathrm{IgG}$, was recovered by centrifugation.

\section{$2^{\text {nd }}$ Viral inactivation, chromatographic purification and formulation}

IgG pure paste was dissolved in water for injection into a quantity equivalent to six times its weight $(\mathrm{kg} / \mathrm{L})$, and its $\mathrm{pH}$ was adjusted to $4.5 \pm 0.2$ with $\mathrm{HCL} 0.5 \mathrm{~N}$, and a clarifying filtration was performed with absolute porosity values of $0.65 \mu \mathrm{m}$. A limpid solution was obtained.

In order to reduce ionic force, IgG solution was diafiltered with water for injection into a quantity equivalent to twice its dissolution volume, followed by protein concentration adjustment to $5 \%$. Diafiltration and protein level adjustment were performed using a $30 \mathrm{KD}$ Millipore Pellicon System.

The solution with low ionic force was subjected to a viral inactivation process by action of a solvent-detergent mixture with Tri-n-butyl phosphate $0.3 \%(\mathrm{~m} / \mathrm{m})$ and Tween $801 \%(\mathrm{~m} / \mathrm{m})$ at $25^{\circ} \mathrm{C}$ (Horowitz, 1992).

A final purification process was performed by ion exchange liquid chromatography with CM Sepharose FF as stationary phase. The system was balanced by four 
volumes of $\mathrm{NaCl} 0.02 \mathrm{M}$ buffer $\mathrm{pH} 4.0$. The sample was injected at 1.5 times the column volume in each cycle. Solvent-detergent mixture elimination was performed by washing of stationary phase with ten times the column volume of glycine buffer solution $0.01 \mathrm{M}$ at $\mathrm{pH}$ 7.0. IgG was eluted with seven volumes of glycine buffer solution $0.1 \mathrm{M}$ plus $\mathrm{NaCl} 0.15 \mathrm{M}$ at $\mathrm{pH} 9.0$

Eluate $\mathrm{pH}$ was adjusted to $4.1-4.3$ with hydrochloric acid buffer solution $0.1 \mathrm{M}$, and diafiltration was performed against 3 volumes of sucralose buffer solution 10\%. Protein levels were adjusted to 5\%. The Millipore Pellicon System was used again, with cutting power of 10KD. The solution was filtered by sterilizing filters and then packaged aseptically.

\section{RESULTS AND DISCUSSION}

The traditional use of methods that employ ethanol in all plasma fractionation steps can be justified by several specific features such as low molecular weight, reduced volatility when cooled, known bacteriostatic property, and recovery possibility due to redistillation. Polyethylene glycol (PEG), however, has a very prominent feature related to preservation of IgG molecular structure: it has no denaturizing action against IgG. In order to reach a synergic result, two types of alcohol were used in the present study: PEG was used for crude purification, and ethanol was used in the last step of the process. IgG crude fraction had $95 \%$ purity, while the gamma fraction in the finished product was $100 \%$ pure. IgG subclasses were distributed identically to human plasma, and the concentrate obtained was potentially effective for use in any situation requiring direct neutralization of antigens, including placental barrier transposition (Grey, 1964). Other gamma-globulins such as IgM and $\operatorname{IgA}$, with molecular weight close to IgG, were not detected. The latter was considered by the authors as the possible culprit for anaphylactic reactions related to the use of immunoglobulins. (Ullmann, 1989)

The methodology presented here can be used in factory-scale production, because it can be linked to other technologies, with no loss in the recovery of coagulation factors and albumin. The average yield of the technique was 3.3 grams of pure IgG for each liter of fractionated plasma.

Inclusion of an ethanol precipitation step in the immunoglobulin separation showed advantages in relation to the elimination of precipitating agent by ultrafiltration. Ultrafiltration flow was higher in the PEG-ethanol combined technique (45 1/hour) compared to purification technique using polyethylene glycol only ( $32 \mathrm{~L} /$ hour). The introduction of an ethanol precipitation step in the $25 \%$ final concentration also brings advantages to the combined process, because it is considered a step in viral reduction (Morgenthaler, 1989).

Two viral inactivation processes were introduced into the methodology, both using validated techniques. The first was the action of caprylic acid $30 \mathrm{mM}$ at $\mathrm{pH}$ 5.1, which has a detergent action on the lipid membrane of enveloped virus. (Parkinnen, 2007). The second methodology for viral inactivation was the action of polysorbate and tri-butyl phosphate (solvent/detergent) mixture, which also acts on viral lipid envelope. There is also the possibility of introducing a viral reduction step by nanofiltration, aimed at eliminating non-enveloped virus such as parvovirus B19 and HVA (Kreil, 2006).

Complementary activity measurements show that the finished product could be injected by intravenous infusion without any undue activation of the complement system (US FDA 2008). The absence of aggregates due to purification by polyethylene glycol lends stability to the molecule, with no need for treatment with enzymes and/or acids that would change molecular structure. The limpid solution obtained reflects this stability. When quantified, the percentage area of the chromatogram corresponding to the aggregates was $0.5 \%$ (Figure 2).

After being subjected to $57^{\circ} \mathrm{C}$ for 50 hours, no changes were observed in the physical features of the solution compared to the same solution not subjected to these temperatures for 50 hours. Purity of IV IgG solution was confirmed by gel electrophoresis, when starting plasma was compared to the obtained solution (Figure 3).

\section{Plasma}

The ELISA test for the finished product was nonreactive during the search for antibodies screened for blood donation, such as anti-HIV ${ }_{1}$ and anti-HIV ${ }_{2}$, and also antibodies against hepatitis B surface antigens. The presence of antibacterial antibodies was detected by hemagglutination. The presence of antiviral antibodies not screened in the blood center was also detected by the ELISA test. Considering that the starting plasma used in the process was collected from a dengue endemic zone (Cordeiro, 2007), anti-dengue IgG high titers were detected in the finished product (average optic density [OD] 35, positive for $\mathrm{OD}>10$ ). The present study should be extended in order to identify the presence of more than one viral subtype in IgG concentrate, which could potentially cause ADE (antibody dependent enhancement) phenomenon if the product were indicated for dengue cases (Figueiredo, 1999). The results are displayed in Table I. 


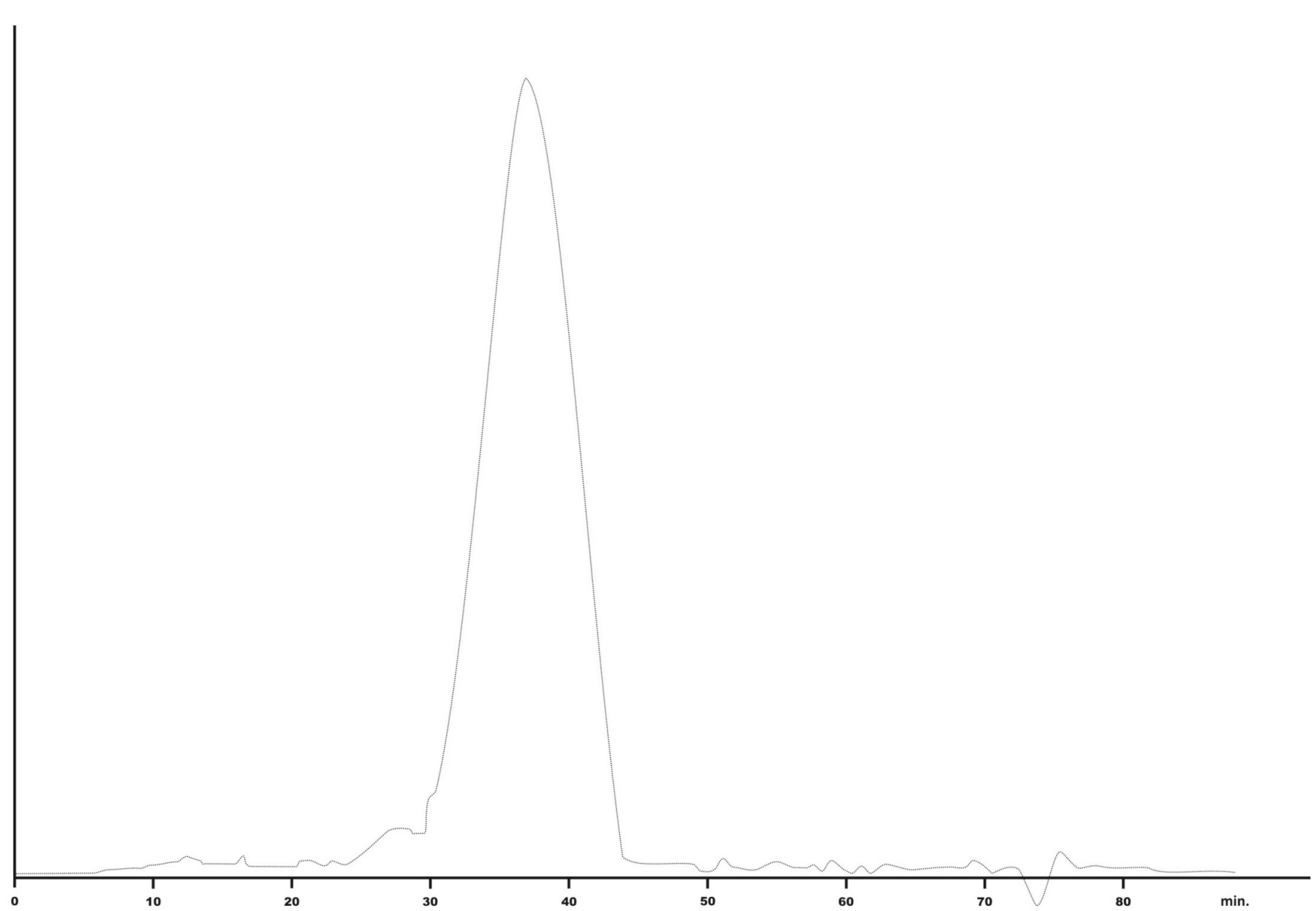

FIGURE 2 - Chromatogram showing the absence of aggregates and a monomer area main peak of $99.5 \%$.

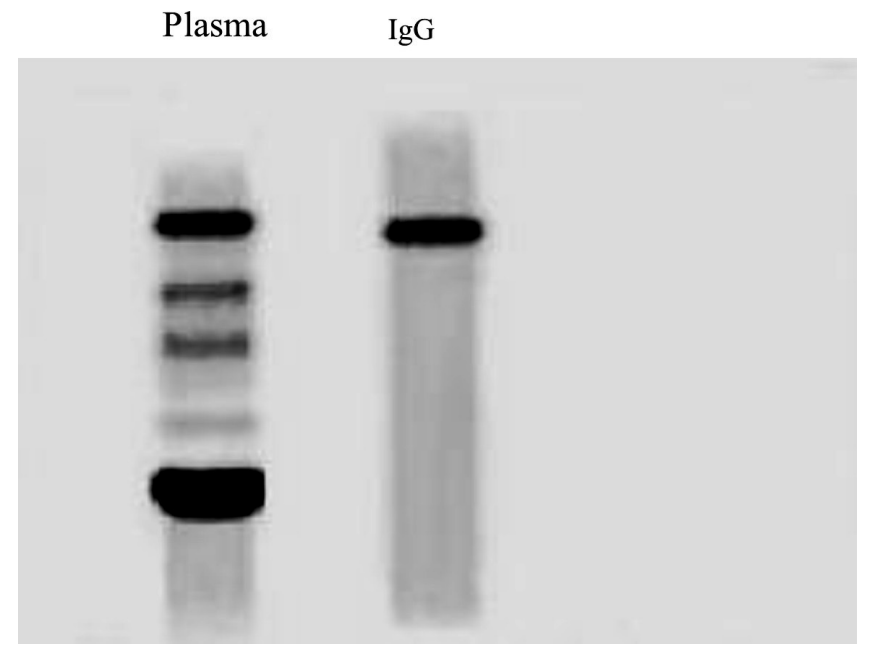

FIGURE 3 - Electrophoresis of fresh plasma sample (left) and of the finished product (IgG 5\%).

\section{CONCLUSION}

The technology developed by the authors of the present paper showed high yield levels in the production of intact $\mathrm{IgG}-3.3 \mathrm{~g} /$ liter of plasma. The method has potential to offer higher productivity than the Cohn-Oncley method, because the precipitation time of the fractions obtained by ethanol is higher than in the fractions obtained using polyethylene glycol. It also enables introduction of several parallel technologies in order to improve the finished product purification process, and also allows linking of this method to other plasma fractionation methodologies. It is important to emphasize that thermal stability at $57^{\circ} \mathrm{C}$ for 54 hours allows the development of another viral inactivation step. The method described here can certainly help fractionation centers to develop, or improve, their techniques for production of IV IgG concentrates, with intact molecules and preserved subclasses, increasing the range of indications and also enhancing the chances of therapeutic success.

\section{ACKNOWLEDGMENTS}

The present project was partially funded by grants from INCT-MCT in Dengue (process: \# 573876/2008-8), and PPSUS-FACEPE (process: \#APQ-1380-4.00/08) and by funding support from the Hematology and Hemothera- 
TABLE I - Biochemical/Immunological Characterization of 5\%. IgG IV solution

\begin{tabular}{ccc}
\hline & Immunobiochemical Characterization & \\
\hline Analysis* & Normal values & Result \\
Protein Conc. & $50 \mathrm{mg} / \mathrm{mL} \pm 10 \%$ & $52 \mathrm{mg} / \mathrm{mL}$ \\
Protein Content (pureness) & Minimum of $95 \%$ IgG & Minimum of $100 \%$ IgG \\
Subclass distribution & Percent & Percent \\
$\mathrm{IgG}_{1}$ & & \\
$\mathrm{IgG}_{2}$ & $65-70$ & 64 \\
$\mathrm{IgG}_{3}$ & $20-25$ & 22 \\
$\mathrm{IgG}_{4}$ & $7-10$ & 8 \\
& $3-6$ & 6 \\
$\mathrm{pH}$ & $4.0-7.4$ & 4.52 \\
$\mathrm{IgA}$ & - & Not detectable \\
$\mathrm{IgM}$ & - & Not detectable \\
Anti-complementary $(\mathrm{CH}$ & & $\leq 1$ \\
Anti-HIV1 antibodies & $\leq 1$ & Absent \\
Anti-HIV2 antibodies & & Absent \\
Anti-HBSAg antibodies & Absent & Absent \\
Anti-Streptococcus antibodies & Absent & Present \\
Anti-parvovirus antibodies & Absent & Present \\
Anti-rubella antibodies & - & Present \\
Anti-dengue antibodies & - & Present \\
Quantification of aggregates & - & $0.5 \%$ \\
Stability at $57^{\circ}$ C/4 $\mathrm{h}$ & - & No gellification \\
\hline
\end{tabular}

py Foundation of Pernambuco (HEMOPE). The authors would like to thank the supporting agencies and also HEMOPE Production Management, Aggeu Magalhães Research Center and Centre Regionale de Transfusion Sanguine de Bordeaux (France), for the technical and scientific support, and also for human resources necessary for the conclusion of the present study.

\section{REFERENCES}

BARANDUN, S.; KISTLER, P.; JEUNET, F.; ISLIKER, H. Intravenous administration of human gamma globulin. Vox Sang., v.7, p.157-174, 1962.

BERGER, M. Principles of and advances in immunoglobulin replacement therapy for primary immunodeficiency. Immunol. Allergy Clin. N. Am., v.28, p.413-437, 2008.

BRASIL. Agência Nacional de Vigilância Sanitária. RDC n ${ }^{\circ}$ 46, de 18 de Maio de 2000 (DOU 19/05/00) - Normatiza os processos de produção e controle de qualidade, a aquisição e distribuição dos medicamentos hemoderivados para uso humano. Available at: <http://www.anvisa.gov.br>. Accessed on: 25 sep. 2009.
BUCHACHER, A.; IBERER, G. Purification of intravenous immunoglobulin $\mathrm{G}$ from human plasma - aspects of yield and virus safety. Biotechnol. J., v.1, p.148-163, 2006.

CHANG, C. E.; EO, H.G.; LEE, Y.S.; CHUNG, S.K.; SHIN, J.S.; LAH, Y.K.; PARK, C.W.; JUNG, J.T.; HUH, J.W.; LEE, S.M. Human intravenous immunoglobulin preparation and virus inactivation by pasteurization and solvent detergent treatment. Prep. Biochem. Biotechnol., v.30, p.177-197, 2000.

COHN, E. J.; STRONG, L. E.; HUGHES, W. L. J. R.; MULFORD, D. J.; ASHWORTH, J. N.; MELIN, M.; TAYLOR, H. L. Preparation and properties of serum and plasma proteins III. A system for the separation into fractions of the protein and lipoprotein components of biological tissues and fluids. $J$. Am. Chem. Soc., v.68, p.459-475, 1946.

CORDEIRO, T. M.; SILVA, M. A.; BRITO, A.A.C.; NASCIMENTO, M.J.E.; MAGALHÃES, F.C.M.; GUIMARÃES, F.G.; SILVA, L.N.; CARVALHO, F.M.E.; MARQUES, A. T. E. Characterization of a dengue patient cohort in Recife, Brazil. Am. J. Trop. Med. Hyg. v.77, p.1128-1134, 2007. 
CURLING, J. M. Methods of plasma protein fractionation. London: Academic Press, 1980. 205 p.

FIGUEIREDO, L.T.M. Pathogenesis of dengue virus infections. Medicina, Ribeirão Preto, v.32, p.15-20, 1999.

GREY, H. M.; KUNKEL, H.G. H. Chain subgroups of myeloma proteins and normal 7S gamma-globulin. J. Exp. Med., v.120, p.253-266, 1964.

HARLOW, E.; LANE, D. Anticorps: un manuel de laboratoire. Paris: Éditions Pradel, 1991. 725 p.

HOROWITZ, B.; WIEBE, M.E.; LIPPIN, A.; STRYKER M.H. Inactivation of viruses in labile blood derivatives. Disruption of lipid-enveloped viruses by tri(n-butyl) phosphate detergent combinations. Transfusion, v.25, p.516-522, 1985.

IMBACH P., (Ed.). Immunotherapy with intravenous immunoglobulins. London: Academic Press, 1991. 180 p.

LEBING, W.; REMINGTON, K.M.; SCHREINER, C; PAUL, H.I. Properties of a new intravenous immunoglobulin (IGIV-C, 10\%) produced by virus inactivation with caprylate and column chromatography. Vox Sang., v.84, p.193-201, 2003.

LUNDBLAD, J. L.; SENG, R. L. Inactivation of lipid-enveloped viruses in proteins by caprylate. Vox Sang., v.60, p.75-81, 1991.

KREIL, T.R.; WIESER, A.; BERTING, A.; SPRUTH, M.; MEDEK, C.; PÖLSLER, G.; GAIDA, T.; HÄMMERLE, T.; TESCHNER, W.; SCHWARZ .H-P.; BARRETT, P. $\mathrm{N}$. Removal of small nonenveloped viruses by anti-bodyenhanced nanofiltration during manufacture of plasma derivatives. Transfusion, v.46, p.1143-1151, 2006.

KROEZ, M, KANZY, E-J, GRONSKI, P, DICKNEITE, G. Hypotension with intravenous immunoglobulin therapy: importance of $\mathrm{pH}$ and dimer formation. Biologicals, v.31, p.277-286, 2003.
MARTHA, M.; EIBL, M.D. History of immunoglobulin replacement - immunology Allergy Clin. N. Am., v.28, p.737-764, 2008.

MORELL, A.; NYDEGGER, U.E.; (Eds.). Clinical use of intravenous immunoglobulins. London: Academic Press, 1986. $320 \mathrm{p}$.

MORGENTHALER, J.J. Effect of ethanol and viruses. Curr. Stud. Hematol. Blood Transfus., v.56, p.109-121, 1989.

ONCLEY, J.L.; MELIN, M.; RICHERT, D.A.; CAMERON, J.W.; GROSS, P.M. Jr: The separation of the antibodies, isoaglutinins, prothrombin, plasminogen and betalipoprotein into subfractions of human plasma. J. Am. Chem. Soc., v.71, p.541-550, 1949.

PARKKINEN, J. A process for the manufacture of virus safe immunoglobulin. US PATENT 0244305 Oct. 18, 2007.

BOACKLE J.R; JOHNSON, J.B.; CAUGHMAN, B.G. An $\mathrm{IgG}$ primary sequence exposure theory for complement activation using synthetic peptides. Nature, v.282, p.742743, 1979.

ROBERTS, P. Global demand for plasma products. In: INTERNATIONAL PLASMA PROTEIN CONGRESS, Prague, 2006 Proceedings. Zeist: The Netherland. Medical Forum International B.V, 2006. p.39-68.

SCHULTZE, H.E.; SCHWICK, G. Uber neue Möglichkeiten intravenöser Gammaglobulin-Applikation. Deuthsche Med. Wchnschr., v.87, p.1643-1650, 1962.

SGOURIS, J.T. The preparation of plasmin treated immune serum globulin for intravenous use Vox Sang., v.13, p.7184, 1967.

STEINBUCH, M. C. The isolation of IgG from mammalian sera with the aid of caprylic acid. Rev. Franç. Trans. Immunol. Hematol., v.13, p.141-151, 1970.

Received for publication on $12^{\text {th }}$ November 2009. Accepted for publication on $24^{\text {th }}$ May 2010. 